\title{
Long-term effects of vasectomy on prostatic function in men
}

\author{
V. K. Naik, U. M. Joshi and A. R. Sheth \\ Institute for Research in Reproduction (Indian Council of Medical Research), \\ Jehangir Merwanji Street, Parel, Bombay 400 012, India
}

\begin{abstract}
Summary. The seminal plasma constituents of acid phosphatase, maltase, citric acid, prolactin, zinc and magnesium were measured in men vasectomized for 1-8 years. Compared with values obtained for a group of normal fertile men, all the constituents, except acid phosphatase which was unchanged, decreased significantly after vasectomy, but not progressively so. Since the constituents measured are believed to be of prostatic origin, the results suggest that vasectomy in men decreases the secretory function of the prostate gland.
\end{abstract}

\section{Introduction}

The past two decades have witnessed the global acceptance of vasectomy as a reliable and effective means of male contraception. However, considerable interest in the possibility of deranged function, particularly of the testis and its dependent organs, has emerged in the recent literature. Altered prostatic function (Thakur, Sheth, Rao \& Thaker, 1975) and epididymal function (Pardanani, Patil \& Pawar, 1976) have been observed following vasectomy, and some effects on accessory organ functions have been found (Naik et al., 1976). Purvis, Saxena, Cekan, Diczfalusy \& Giner (1976) suggested that vasectomy could progressively affect the function of accessory reproductive organs, particularly that of the prostate gland. The studies of Naik et al. (1976) and Purvis et al. (1976) were both, however, of short duration, covering only the 6-12 months after vasectomy.

The present study was therefore designed to investigate the long-term effects of vasectomy on prostatic function.

\section{Materials and Methods}

The 78 men studied were aged 24-45 years and had been vasectomized 1-8 years previously. The control group consisted of 22 men of normal fertility who were matched with the vasectomized men for geographical area, socio-economic background, race and age.

Semen was collected by masturbation after abstinence for 3-4 days and allowed to liquefy at room temperature for $30 \mathrm{~min}$ and then centrifuged at $800 \mathrm{~g}$ for $15 \mathrm{~min}$ at $4^{\circ} \mathrm{C}$. Seminal plasma was separated and stored at $-20^{\circ} \mathrm{C}$ in small aliquots.

Seminal plasma concentrations of acid phosphatase, citric acid, maltase, prolactin, zinc and 
magnesium were measured. Acid phosphatase activity was measured by the method of Bergmeyer (1965) immediately after the separation of seminal plasma using $p$-nitrophenylphosphate as substrate. The intra-assay coefficient of variation of this method was $<12 \%$. Maltase activity was measured by the method of Rao, Sheth \& Gunaga (1969), immediately after the separation of seminal plasma. The intra-assay coefficient of variation of this method was $5 \%$. Citric acid concentration was estimated using the method of Beutler \& Yeh (1969). The intra- and inter-assay coefficients of variation of this method were 5.6 and $8 \%$ respectively.

Prolactin was estimated by a double-antibody RIA method similar to that described by Midgley (1966) for luteinizing hormone. Human prolactin (VLS, No. 4) and its antiserum (AFPantihPrl, No. 1) were obtained from NIAMDD, NIH, Bethesda, Maryland, U.S.A. To $500 \mu \mathrm{l}$ phosphate buffered saline, $\mathrm{pH} 7 \cdot 4$, containing 100 or $200 \mu \mathrm{l}$ seminal plasma, were added $200 \mu \mathrm{l}$ of suitably diluted $(1: 8000)$ antiserum to human prolactin and the mixture was incubated at $4^{\circ} \mathrm{C}$ for $24 \mathrm{~h}$. Labelled human prolactin was added and the mixture was incubated for an additional $24 \mathrm{~h}$ at $4^{\circ} \mathrm{C}$. The free hormone was separated from the bound by adding $200 \mu \mathrm{l}$ anti-rabbit $\gamma$ globulin $(1: 50)$ and keeping the tubes at $4{ }^{\circ} \mathrm{C}$ for $48 \mathrm{~h}$. The sensitivity of the assay was $1 \mathrm{ng}$ prolactin/ml seminal plasma. The intra- and inter-assay coefficients of variation were 8 and $11 \%$ respectively.

Zinc and magnesium concentrations were estimated in seminal plasma suitably diluted with distilled water by atomic absorption spectrometry: the light source was a hollow cathode, the flame was air-acetylene (air-rich), the operating lamp current was $8 \mathrm{~mA}$, the band pass was 20 $\mathrm{nm}$ and the wave lengths for zinc and magnesium estimates were 2183.6 and $2852.1 \mathrm{~nm}$ respectively.

The results were evaluated by Student's $t$ test and the $\boldsymbol{P}$ value was obtained from a two-tailed table.

\section{Results}

As shown in Table 1 there was no difference in seminal acid phosphatase activity of the vasectomized and control men, but concentrations of citric acid, maltase, prolactin, magnesium and zinc were significantly lower after vasectomy. When values were expressed per ejaculate, the differences between the two groups became even greater because the mean seminal volume was less in vasectomized men.

Table 1. Effect of vasectomy on semen characteristics of men

\begin{tabular}{cccccccc}
\hline Group & $\begin{array}{c}\text { Volume } \\
(\mathrm{ml})\end{array}$ & $\begin{array}{c}\text { phosphatase } \\
(\mu \mathrm{M} / \mathrm{ml})\end{array}$ & $\begin{array}{c}\text { Citric } \\
\text { acid } \\
(\mathrm{mg} / \mathrm{ml})\end{array}$ & $\begin{array}{c}\text { Maltase } \\
(\mathrm{mg} / \mathrm{ml})\end{array}$ & $\begin{array}{c}\text { Prolactin } \\
(\mathrm{ng} / \mathrm{ml})\end{array}$ & $\begin{array}{c}\text { Zinc } \\
(\mu \mathrm{g} / \mathrm{ml})\end{array}$ & $\begin{array}{c}\text { Magnesium } \\
(\mu \mathrm{g} / \mathrm{ml})\end{array}$ \\
\hline Control men & $2 \cdot 85 \pm$ & $205 \cdot 1 \pm$ & $7 \cdot 22 \pm$ & $17.6 \pm$ & $188 \cdot 8 \pm$ & $209 \cdot 7 \pm$ & $186.9 \pm$ \\
& $0.20(22)$ & $20.7(22)$ & $0.45(22)$ & $1 \cdot 3(22)$ & $11.6(22)$ & $19.7(22)$ & $32 \cdot 3(16)$ \\
\hline $\begin{array}{c}\text { Vasectomized } \\
\text { men }\end{array}$ & $2.01 \pm$ & $192 \cdot 8 \pm$ & $5.61 \pm$ & $3.99 \pm$ & $114.0 \pm$ & $135.0 \pm$ & $99.3 \pm$ \\
\hline
\end{tabular}

Values are mean \pm s.e.m. for the numbers of samples (men) given in parentheses.

Significantly different from control value: ${ }^{*} P<0.05 ; \dagger P<0.01 ; \ddagger P<0.001$.

A good correlation between seminal plasma prolactin and zinc was obtained both for the control $(r=0.53 ; P<0.05)$ and vasectomized $(r=0.63 ; P<0.01)$ men, suggesting that the prostate gland may be the seminal source of prolactin.

When the vasectomized men were grouped according to the different periods after vasectomy (Text-fig. 1), there was no obvious effect of duration of vasectomy. 

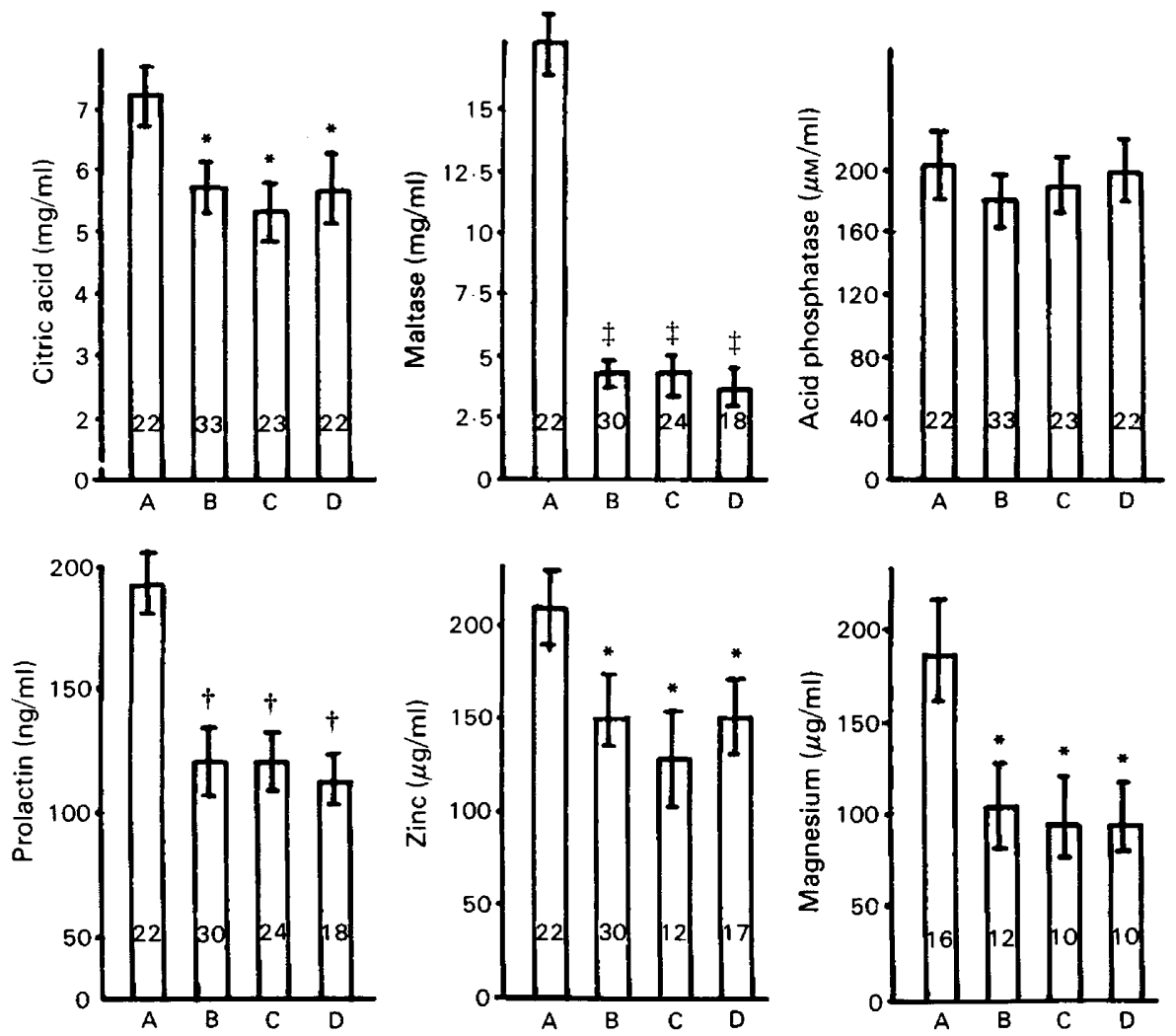

Text-fig. 1. Effects of vasectomy on semen characteristics of men vasectomized for 1-2 years (B), 2-5 years (C), 5-8 years (D) compared with non-vasectomized controls (A). The values are mean \pm s.e.m. for the numbers of samples indicated in the columns. Values significantly different from those in Group A are indicated: ${ }^{*} P<0.05 ; \dagger P<0.01 ; \ddagger P<0.001$.

\section{Discussion}

The prostatic origin of the seminal plasma content of citric acid (Mann, 1964; Sheth \& Rao, 1962), acid phosphatase (Bygdeman \& Eliasson, 1969), maltase (Sheth \& Roa, 1962), zinc (Eliasson \& Lindholmer, 1971; Homonnai, Martzkin, Faiman, Paz \& Kraicer, 1978a) and magnesium (Eliasson \& Lindholmer, 1972; Hommonnai et al., 1978a) and the estimations of such seminal constituents for evaluation of the function of accessory organs is well recognized (Eliasson, 1968).

Sheth, Mugatwala, Shah \& Rao (1975) have demonstrated the presence of prolactin in human semen. Although the source of this prolactin is not known there is evidence to suggest that the prostate gland may be the source (Asano, Kanzaki, Sekiguchi \& Tasaka, 1971). The correlation between seminal plasma concentrations of zinc and prolactin observed in the present investigation and that reported by Homonnai, Paz, Sofer \& Kraicer (1978b) supports this assumption.

In the present study, all the substances investigated except acid phosphatase decreased after vasectomy, and the results are in accordance with those of the short-term study of Thakur $e t$ al. (1975), indicating that vasectomy decreases prostatic function. Purvis et al. (1976) observed a decrease in dihydrotestosterone concentration in the seminal plasma of vasectomized men and suggested that vasectomy might decrease certain aspects of prostatic function to cause reduced 
conversion of testosterone to dihydrotestosterone. Pierrepoint \& Davies (1973) studied rats and suggested that vasectomy could affect prostatic nucleic acid content as well as nucleic acid metabolism. A significant lowering of the weight of the ventral prostate in vasectomized rats has also been reported (Kinson \& Layberry, 1975).

The significance of the observation in the present studies that vasectomy did not lead to any significant changes in the acid phosphatase activity is not clear. Many studies have suggested that the different secretory products of the same organ may not have good correlation. For example, poor correlation has been reported between total protein and fructose, albumin and zinc, and albumin and acid phosphatase activity in human seminal plasma (Bygdeman \& Eliasson, 1969; Eliasson \& Lindholmer, 1971, 1972). The human prostate does not have an homogeneous structure (Andrews, 1951) and the different regions of the prostate respond differently to hormones (Huggins \& Webster, 1948), and have different biochemical composition. For example, the ventral and the lateral portions of the human prostate contain more acid phosphatase than does the dorsal portion (Gomori, 1941). The maltase activity in the human prostate is localized predominantly in the middle and lateral region (Gunaga, Sheth \& Rao, 1968). Similarly, in the rat, the lateral region of the prostate concentrates zinc (Gunn \& Gould, 1956, 1957), and dithiozone, which is a zinc chelating agent, causes selective necrosis of the lateral prostate without affecting other lobes. It is therefore possible that the different regions of the human prostate have different responses to vasectomy.

It has been proposed that, in adult animals, there is direct testicular control over the function of the accessory reproductive organs via the vas deferens (Pierrepoint, Davies, Lewis \& Moffat, 1975). Vasectomy could therefore result in the removal of such a control, resulting in the decreased function of the accessory organs (Skinner \& Rowson, 1968a, b; Pierrepoint \& Davies, 1973). The suppressed prostatic function after vasectomy in men could be due to the removal of such a direct control.

We thank Mr Raut and Dr Soman of B.A.R.C. Health Physics Division for their help with zinc and magnesium estimations.

\section{References}

Andrews, G.S. (1951) The histology of the human foetal and prepubertal prostates. J. Anat. 85, 44-54.

Asano, M., Kanzaki, S., Sekiguchi, E. \& Tasaka, T. (1971) Inhibition of prostatic growth in rabbits treated with antiovine prolactin serum. J. Urol. 106, 248-252.

Beutler, E. \& Yeh, M.K. (1969) Simplified method for the determination of citric acid. J. Lab. Clin. Med. 54, 125-131.

Bergmeyer, H.U. (1965) Determination in serum with pnitrophenylphosphate. In Methods of Enzymatic Analysis, pp. 783-785. Ed. H. U. Bergmeyer. Academic Press, New York.

Bygdeman, M. \& Eliasson, R. (1969) Distribution of prostaglandins, fructose and acid phosphatase in human seminal plasma. Andrologia 1, 5-10.

Eliasson, R. (1968) Biochemical analysis of human semen in the study of the physiology and pathology of the male accessory genital glands. Fert. Steril. 19, $344-350$.

Eliasson, R. \& Lindholmer, C. (1971) Zinc in human seminal plasma. Andrologia 3, 147-153.

Eliasson, R. \& Lindholmer, C. (1972) Magnesium in human seminal plasma. Invest. Urol. 9, 286-289.
Gomori, G. (1941) Distribution of acid phosphatase in the tissue under normal and under pathologic conditions. Arch. Path. 32, 189-199.

Gunaga, K.P., Sheth, A.R. \& Rao, S.S. (1968) Localization of maltase and amylase in the human prostate. Indian J. Med. Res. 56, 208-210.

Gunn, S.A. \& Gould, T.C. (1956) Differences between dorsal and lateral components of the dorsolateral prostate of the rat in $\mathrm{Zn}^{65}$ uptake. Proc. Soc. exp. Biol. Med. 92, 17-20.

Gunn, S.A. \& Gould, T.C. (1957) A correlative anatomical and functional study of the dorsolateral prostate of the rat. Anat. Rec. 128, 41-53

Homonnai, Z.T., Martzkin, H., Fainman, N., Paz, G. \& Kraicer. P.F. (1978a) The cation composition of the seminal plasma and prostatic fluid and its correlation to semen quality. Fert. Steril. 29, 539542.

Homonnai, Z.T., Paz, G., Sofer, A. \& Kraicer, P.F. (1978b) Prolactin and zinc in the human ejaculate. Andrologia 10, 66-68.

Huggins, C. \& Webster, W.o. (1948) Duality of human prostate in response to estrogen. $J$. Urol. 59, 258266. 
Kinson, G.A. \& Layberry, R.A. (1975) Long term endocrine response to vasectomy in the adult rat. Contraception 11, 143-149.

Mann, T. (1964) The Biochemistry of Semen and of the Male Reproductive Tract. Methuen, London.

Midgley, A.R., Jr (1966) Radioimmunoassay: a simplified method for human chorionic gonadotropin and human luteinizing hormone. Endocrinology 79, 10-18.

Naik, V.K., Thakur, A.N., Sheth, A.R., Joshi, U.M., Rao, S.S., Pardanani, D.S., Kulsreshtha, J.K. \& Handa, R.K. (1976) Effect of vasectomy on pituitary-gonadal function in men. $J$. Reprod. Fert. 48, 441-442.

Pardanani, D.S., Pati, N.G. \& Pawar, H.N. (1976) Some gross observations of the epididymides following vasectomy: a clinical study. Fert. Steril. 27, 267270.

Pierrepoint, C.G. \& Davies, P. (1973) The effect of vasectomy on the activity of prostatic RNA polymerase in rats. J. Reprod. Fert. 35, 149-152.

Pierrepoint, C.G., Davies, P., Lewis, H.H. \& Mofiat, D.B. (1975) Examination of the hypothesis that a direct control system exists for the prostate and seminal vesicles. J. Reprod. Fert. 44, 395-409.
Purvis, K., Saxena, S.K., Cekan, Z., Diczfalusy, E. \& Giner, J. (1976) Endocrine effect of vasectomy. Clin. Endocr. 5, 263-268.

Rao, S.S., Sheth, A.R. \& Gunaga, K.P. (1969) Assay of androgenicity of steroids using maltase activity of dorsal prostate of the rat as an index. Indian J. exp. Biol. 7, 20-22.

Sheth, A.R. \& Rao, S.S. (1962) Purification and properties of human seminal maltase. J. Reprod. Fert. 4, 267-276.

Sheth, A.R., Mugatwala, P., Shah, G.V. \& Rao, S.S. (1975) Occurrence of prolactin in human semen. Fert. Steril. 26, 905-907.

Skinner, J.D. \& Rowson, L.E.A. (1968a) Some effects of unilateral cryptorchism and vasectomy on sexual development of the pubescent ram and bull. $J$. Endocr. 42, 311-321.

Skinner, J.D. \& Rowson. L.E.A. (1968b) Effect of testosterone injected unilaterally down the vas deferens on the accessory glands of the ram. $J$. Endocr. 42, 355-356.

Thakur, A.N., Sheth, A.R., Rao, S.S. \& Thaker, P.V. (1975) Prostatic function in vasectomized men. Contraception 11, 155-159.

Received 13 February 1979 